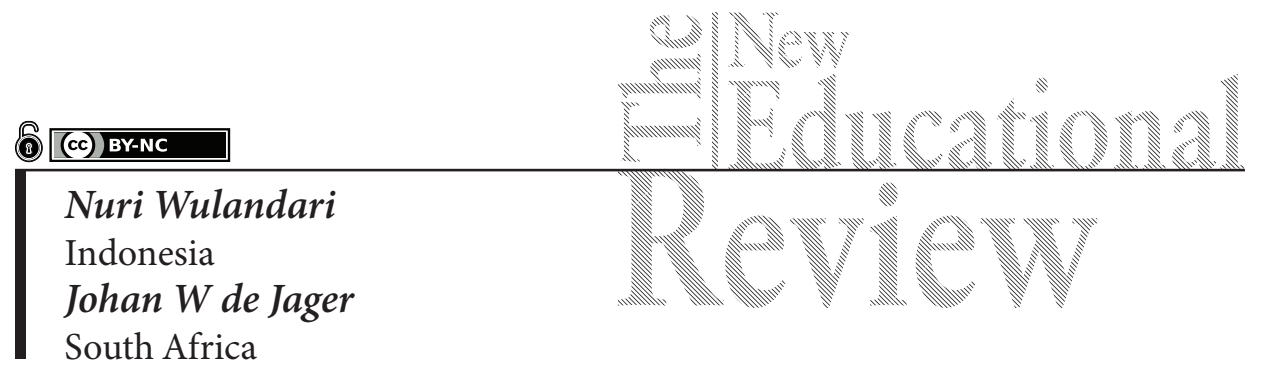

\title{
Students' Expectations of Higher Educational Experience in Public vs. Private Universities in Indonesia
}

DOI: 10.15804/tner.2018.54.4.12

\begin{abstract}
In the education industry, it is critical to understand the expectations of students concerning providing the best educational experience. Thus, in higher education institutions (HEI) the adoption of customer-oriented approaches in the management practice is widespread. The customer-oriented approach regarding students as customers has been discussed in academic literature from several perspectives. However, it has been rarely studied from the point of view of comparing public and private universities. The presented study tried to apply a student-customer orientation questionnaire (SCOQ) to investigate differences between student expectations of their educational experience in public vs. private universities. The sample consisted of 238 undergraduate students in Indonesia's higher education institutions. The study found interesting differences within the student-customer-oriented variables between university types in terms of graduation, curriculum design, communication with service staff, classroom studies, individual studies and course design.
\end{abstract}

Keywords: higher education institution, consumer behaviour, marketing, customer-oriented, university, study experience 


\section{Introduction}

Higher education institutions (HEI) are currently facing a competitive landscape. In response to competition, there are arguments that HEI ought to adopt a customer-oriented approach from the marketing discipline. Customer orientation is defined as sufficient understanding of one's target buyers to be able to create continuous superior value for them (Narver \& Slater, 1990). The definition also represents the tendency of employees within an organization to meet customers' needs in their job situation (Brown, Mowen \& Licata, 2002). A university which adopts customer orientation will try to understand and to assess the student's perception of the education experience in order to meet their educational needs. This effort needs strong commitment from the higher education institution as well as implementation of marketing concepts and methods. Nevertheless, the marketing approach is considered a necessity for the success of the management of higher education institutions (Amiri, Ranjbar, Zamani, 2015). It is argued that higher educational institutions as business organizations should also employ the customer orientation approach (Greenberg, 2004). Thus the challenge is how to use this concept, at the same time upholding academic integrity (Guibault, 2018), especially in the increasingly competitive environment of HEI industry.

Positioning a HEI as a student-customer oriented institution has been extensively discussed. However, there are still limited studies of the context of university types comparing public and private higher education institutions. The comparison between the two types is important due to the fact that nowadays higher education institutions, especially in Asia, experience a decline in state funding for public universities (UNESCO, 2014). The situation has forced public universities to adapt and even change their status into private universities. Hence, the competition landscape is becoming more intense and needs a thorough understanding of students' expectations of the educational experience in order to excel within the market.

In this light, the presented study tries to understand differences of students demand in each category of public HEI and private HEI. The main objectives, therefore, translate into two specific questions. First, in which categories (or variables) do students expect a HEI to be student-customer oriented? Second, is there any difference between university type (public vs. private HEI) in terms of the category of expectation? 


\section{Research Methodology}

\section{Research General Background}

In literature, there are three streams of opinions regarding implementation of market orientation in higher education industry. The first one focuses on the customers due to the falling demand for education from students' prospective. This study suggests that focusing on students as customers is necessary in the situation of decreasing demand for education (DeShields et al., 2005; Pesch et al., 2008; Svensson \& Wood, 2007). The second stream is a strong opinion that using marketing to solve HEI's problems is not a solution, albeit it contributes to new challenges (Argenti, 2000; Eagle \& Brennan, 2007). This stream suggests that marketing metaphors are inappropriate to describe the student-university relationship. The student-university relationship has no analogy to traditional marketing relationships such as customer-supplier or buyer-seller (Shupe, 1999). The first two streams are positioned in contrasting poles. This situation might occur due to the insufficient understanding of contemporary marketing. Marketing as a discipline has evolved from sales orientation to marketing orientation, from selling products to value creation. HEI should move from marketization towards marketing of higher education (Judson \& Taylor, 2014). The last stream is adiscussion on the student's experience as a basis for market orientation. Muncy (2008) claims that HEI contains many educational experiences such as curriculum, pedagogy and feedback. Koris and Nokelainen (2015) provide a useful conceptual framework for educational experience, which divides educational experiences in HEI into two parts including Institutional Network and Learning Situation network.

\section{Research Design and Sampling}

The study can be categorized as quantitative-descriptive research showing relationships between variables (Churcill \& Iobucci, 2002) and also ascertaining and describing the characteristics of variables under study (Sekaran, 2010). It is a single cross-sectional design, where only one sample of respondents is drawn from the target population and information is obtained from the same sample (Maholtra, 2010). The unit of analysis of the study is the students of higher education institutions (HEI) in Jakarta and closest suburban areas, as many prominent universities are located in these areas. Using a survey, the sample size for this research follows Gorsuch (1983), who suggested a 5:1 ratio of the number of observations to the number of indicators. The sample involved students, 18 years of age and older, and in the process of obtaining their undergraduate education or just graduated within the last 6 months. The data was processed using SPSS. 


\section{Instrument and Procedures}

The study used Koris and Nikoilanen (2015) Student-Customer Oriented Questionnaire, with several modifications on the indicators selected for the final instrument. The presented study contains the original 14 categories (90 questions). The selection of the items that were kept in the end was based on maximizing the Cronbach Alpha for each category. Back to back translation was conducted before the survey was pre-tested to a small number of respondents. The item questions comprised six-point Likert type scale questions, which describe the level of agreement from strongly disagree (1) to strongly agree (6) .

\section{Research Results}

Out of the 250 questionnaires collected, a total of 238 usable questionnaires were processed. The respondents' profiles are presented in the table according to the type of university and gender. Most of the respondents are female, $57.9 \%$, as compared to $42.1 \%$ of male ones. A large percentage of the sample are students of the $3^{\text {rd }}(38.3 \%)$ and $4^{\text {th }}$ year $(26.3 \%)$ of study in higher education institutions. The respondents' source of funding is mostly their parents (81.7\%). $84.6 \%$ of the respondents admitted not working at the moment, while the remaining students are working and studying at the same time. Almost 70\% (69.2) of the respondents surveyed are students of private-owned HEIs, while the rest (32.5\%) are students of public HEIs.

\section{Instrument Reliability}

The study used Cronbach's alpha to measure the reliability or internal consistency of the variables. The Cronbach Alpha of 0.7 was considered satisfactory to measure the acceptable reliability level for the measurements following Nunnaly (1978). The result showed that within institutional network, categories that have acceptable internal consistency are student feedback, communication with service staff and discipline. Within the Learning Situation Network, teaching methods and course design have the highest internal consistency.

The result of this study validates student feedback as a highly important category $(\mathrm{M}=4.866 ; \mathrm{SD}=0.158)$. The construct has good reliability, shown by the Cronbach Alpha of 0.826 . Students agree that HEI should collect the feedback, follow up and communicate the changes based on the feedback to the students. It includes the teachers' feedback and resolves the students' dissatisfaction. The importance of student feedback is confirmed by many studies (Koris, 2012; Hussey and Smith, 2010; Muncy, 2008). 
Table 1. Student-customer orientation categories (all sample)

\begin{tabular}{|c|c|c|c|c|}
\hline $\begin{array}{l}\text { Category } \\
\text { Number }\end{array}$ & Category & Mean & $\begin{array}{l}\text { Standard } \\
\text { Deviation }\end{array}$ & $\begin{array}{c}\text { Cronbach's } \\
\text { Alpha }\end{array}$ \\
\hline \multicolumn{5}{|c|}{ Institutional Network } \\
\hline 1 & Admission & 3.358 & 0.613 & 0.490 \\
\hline 2 & Student feedback & 4.866 & 0.158 & 0.826 \\
\hline 3 & Graduation & 4.056 & 0.701 & 0.600 \\
\hline 4 & Curriculum design & 4.239 & 0.442 & 0.672 \\
\hline 5 & Communication with service staff & 3.71 & 0.42 & 0.806 \\
\hline 6 & Discipline & 4.404 & 0.927 & 0.817 \\
\hline \multicolumn{5}{|c|}{ Learning Situation Network } \\
\hline 7 & Grading & 4.538 & 0.386 & 0.773 \\
\hline 8 & Classroom behaviour & 4.227 & 0.386 & 0.756 \\
\hline 9 & Student-teacher relationship & 4.663 & 0.927 & 0.713 \\
\hline 10 & Communication with teacher & 4.617 & 0.424 & 0.592 \\
\hline 11 & Classroom studies & 4.667 & 0.436 & 0.793 \\
\hline 12 & Individual studies & 3.615 & 0.44 & 0.683 \\
\hline 13 & Teaching methods & 4.565 & 0.255 & 0.830 \\
\hline 14 & Course design & 4.219 & 0.29 & 0.809 \\
\hline
\end{tabular}

Discipline is the level of strictness that the students expect the HEI to apply. The result shows that, on average, the students agree to obey the HEI's rules and regulations $(\mathrm{M}=4.404$; $\mathrm{SD}=0.927)$. They believe that the HEI should be strict in having the students meet deadlines, that rule-breaking should be punished and that the same rules should apply to all students. This shows that the students demand fairness from the HEI. The Cronbach Alpha shows that this construct also has good reliability (0.817).

Communication with service staff gave interesting results. According to the responses, the students expect to be treated as customers $(M=3.71 ; S D=0.420)$. They consider it the service staff's responsibility to inform them as soon as possible of any changes to adjust their schedule in the way that suits the students best and help them to solve problems related to deadlines. The construct showed internal consistency with the Cronbach Alpha of 0.806 .

In terms of teaching methods, the students expect teaching to be fun and interactive $(\mathrm{M}=4.565 ; \mathrm{SD}=0.255)$. This is confirmed by literature, according to 
which students want studying to be entertaining and based on as many interactive methods as possible (Koris, 2012). Cronbach's Alpha for this construct is 0.830 .

Regarding the construct of course design, the students agree that the teacher decides on the topics $(M=4.219 ; \mathrm{SD}=0.290)$. Nevertheless, the students also want the material to be practical as opposed to theoretical. They also think that lecturers should be active in their field of knowledge outside the institution. This construct also showed good reliability, with the Cronbach Alpha of 0.809 .

\section{Public vs. Private University}

An independent t-test was conducted to answer whether there were any differences in perceptions regarding the HEI experience in terms of the respondents' demographic profiles. The study also measured the size of the difference between the perceptions of the public and private university students on each of the categories investigated. The size was measured by calculating the value of Cohen's $d$, Gates delta and Hedges' $g$. The results were then referred to the effect's size level by Cohen (1998) and Sawilowsky (2009), to provide the value reference of very small $(\mathrm{d}=0.01)$ to huge $(\mathrm{d}=2.00)$.

The results show a difference in some of the categories of both institutional network and learning situation network. In the institutional network, the categories that showed significant differences between the public and private university students' perceptions are graduation, curriculum design and communication with the service staff, whereas in the learning situation network, the categories are classroom studies, individual studies and course design.

In the graduation construct, the test indicates that the public university students have different perceptions on graduation, as compared to the private university students, $t(238)=0.02, \mathrm{p}<.05$. On average, the public university students agree slightly less with the statements in the graduation construct (mean=3.87), as compared to the private university students (mean $=4.14$ ). The difference, however, is small according to Cohen's d effect size $(\mathrm{d}=0.33)$.

In the curriculum design construct, the test shows that the public university students have different perceptions on graduation, as compared to the students of private universities, $\mathrm{t}(238)=0.03, \mathrm{p}<.05$. On average, the private university students agree slightly more with the statements in the curriculum design construct (mean=4.31), as compared to the public university students (mean=4.08). The difference, however, is small according to Cohen's d effect size $(\mathrm{d}=0.31)$.

In the communication with staff construct, the test indicates that the public university students have different perceptions on communication with staff, as compared to the private universities students, $\mathrm{t}(238)=0.02, \mathrm{p}<.05$. On average, the 
private university students agree slightly more with the statements in the communication with staff construct (mean $=3.81$ ), as compared to the public university students (mean=3.46). The difference, however, is small according to Cohen's d effect size $(\mathrm{d}=0.31)$.

Regarding the classroom studies construct, the test shows that the public university students have a different perceptions on classroom studies, as compared to the private university students, $\mathrm{t}(238)=0.04, \mathrm{p}<.05$. On average, the private university students agree slightly more with the statements in the classroom studies category $($ mean $=4.75)$, as compared to the public university students (mean=4.48). The difference, however, is small according to Cohen's d effect size $(\mathrm{d}=0.29)$.

In the individual study construct, the test indicates that the public university students have different perceptions on individual studies, as compared to the private university students, $\mathrm{t}(238)=0.04, \mathrm{p}<.05$. On average, the private university students agree slightly more with the statements in the individual studies construct (mean $=3.70)$, as compared to the public university students (mean=3.43). The difference, however, is small according to Cohen's $d$ effect size $(\mathrm{d}=0.29)$.

In the course design construct, the test shows that the public university students have different perceptions on course design, as compared to the private university students, $\mathrm{t}(238)=0.01, \mathrm{p}<.05$. On average, the private university students agree slightly more with the statements in the course design construct (mean=4.32), as compared to the public university students (mean=3.98). The difference, however, is small according to Cohen's d effect size $(\mathrm{d}=0.39)$.

Table 2. Independent sample test (University Type)

\begin{tabular}{lccccccccc}
\hline & \multicolumn{2}{c}{ Public } & \multicolumn{2}{c}{ Private } & \multicolumn{4}{c}{$\begin{array}{c}\text { Levene's test } \\
\text { for equality of } \\
\text { variances }\end{array}$} & \multicolumn{2}{c}{$\begin{array}{c}\text { t-test for equality of } \\
\text { means }\end{array}$} \\
\hline UNITYPE & Mean & $\begin{array}{l}\text { Std. } \\
\text { Dev }\end{array}$ & Mean & $\begin{array}{c}\text { Std. } \\
\text { Dev }\end{array}$ & F & Sig & t & df & $\begin{array}{c}\text { Sig.2 } \\
\text { Tailed }\end{array}$ \\
\hline ADM & 3.47 & 1.12 & 3.31 & 1.15 & 0.10 & 0.75 & 0.98 & 238 & 0.33 \\
\hline STUFED & 4.71 & 0.86 & 4.93 & 0.89 & 0.01 & 0.94 & -1.79 & 238 & 0.08 \\
\hline GRAD & 3.87 & 0.78 & 4.14 & 0.85 & 1.44 & 0.23 & -2.35 & 238 & 0.02 \\
\hline CURR & 4.08 & 0.68 & 4.31 & 0.77 & 1.73 & 0.19 & -2.15 & 238 & 0.03 \\
\hline COMM & 3.46 & 1.05 & 3.81 & 1.05 & 0.00 & 0.99 & -2.35 & 238 & 0.02 \\
\hline RIGR & 4.29 & 0.89 & 4.45 & 0.90 & 0.19 & 0.67 & -1.23 & 238 & 0.22 \\
\hline GRDI & 4.42 & 0.86 & 4.59 & 0.81 & 0.20 & 0.66 & -1.46 & 238 & 0.15 \\
\hline CLASB & 4.36 & 0.76 & 4.17 & 0.81 & 0.56 & 0.45 & 1.68 & 238 & 0.09 \\
\hline STREL & 4.64 & 0.92 & 4.67 & 0.96 & 1.26 & 0.26 & -0.25 & 238 & 0.80 \\
\hline
\end{tabular}




\begin{tabular}{lccccccccc}
\hline & \multicolumn{2}{c}{ Public } & \multicolumn{2}{c}{ Private } & \multicolumn{4}{c}{$\begin{array}{c}\text { Levene's test } \\
\text { for equality of } \\
\text { variances }\end{array}$} & \multicolumn{2}{c}{$\begin{array}{c}\text { t-test for equality of } \\
\text { means }\end{array}$} \\
\hline UNITYPE & Mean & $\begin{array}{l}\text { Std. } \\
\text { Dev }\end{array}$ & Mean & $\begin{array}{c}\text { Std. } \\
\text { Dev }\end{array}$ & F & Sig & t & df & $\begin{array}{c}\text { Sig.2 } \\
\text { Tailed }\end{array}$ \\
\hline COMT & 4.55 & 1.02 & 4.64 & 1.06 & 0.32 & 0.57 & -0.62 & 238 & 0.54 \\
\hline CLASTU & 4.48 & 0.92 & 4.75 & 0.89 & 0.17 & 0.68 & -2.10 & 238 & 0.04 \\
\hline INSTU & 3.43 & 0.92 & 3.70 & 0.92 & 0.23 & 0.63 & -2.09 & 238 & 0.04 \\
\hline TEACM & 4.43 & 0.80 & 4.63 & 0.86 & 0.84 & 0.36 & -1.69 & 238 & 0.09 \\
\hline COURD & 3.98 & 0.86 & 4.32 & 0.88 & 0.71 & 0.40 & -2.80 & 238 & 0.01 \\
\hline SAT & 3.65 & 0.73 & 3.47 & 0.82 & 3.09 & 0.08 & 1.61 & 238 & 0.11 \\
\hline
\end{tabular}

\section{Discussion}

The objective of the study was to investigate the categories, according to which students expect a HEI to be customer oriented. It also investigated the difference between public higher education institutions and private education institutions. The study provides interesting findings and answers to the research question. The results indicate that within the top five constructs that obtained the highest reliability measures, there are constructs showing that the students expect to be served as customers and thus want to have control and decision power. These constructs are student feedback, communication with staff and teaching method. However, there are constructs indicating that control and decision power are expected in the higher education institution and the students accept the regulation. The latter refers to the course design and discipline constructs. Hence, being customer oriented does not mean giving all decision power to the students in all aspect of higher education, but to find balance between students and HEI according to the expectations of each aspect.

Concerning the students' feedback, the students expect the HEI to collect feedback, follow up and communicate the changes based on the feedback to the students. It includes the lecturers' feedback and resolving the students' dissatisfaction. The students also want communication with service staff to be supportive in their academic needs. This is especially applicable to the students from private universities, as compared to the public university students. Regarding the teaching methods, all the students prefer entertaining and engaging lecturers delivering applicable materials. 
For the course design construct, the students depend on the HEI to decide on the course design. However, they would like to have more practical content than a theoretical approach. This is more prominent in the private universities compared to public universities. However, contrary to literature, the students still prefer strict rules imposed by the HEI as well as a sense of fairness in the learning environment regarding rule-breakers.

The research also showed that in several constructs (graduation, curriculum design, communication with service staff, classroom and individual studies and course design) there are significant differences between the students studying in public HEIs and private HEIs. Overall, the private university students are more demanding in terms of the constructs stated, looking at the higher mean score, as compared to the public university students.

\section{Conclusions}

The study has provided insights into the implementation of customer orientation focused on the education industry. First, there should be an effective feedback-follow up system within an education institution to ensure that the voice of students is heard and steps are taken towards improvement based on the feedback. Secondly, there should be clear, consistent communication between students and HEIs. The service staff, as a bridge between the students and lecturers, should be trained to improve service quality. Thirdly, course design should lean more toward practical application and relevance to industry. Teaching should engage students in an interactive manner. Teachers should be encouraged to be involved in activity outside of HEI (practice) or industry related activities.

In addition, the results validated the fact that public university students only marginally differ from private university students. It can be inferred that private university students in general are slightly more demanding, as compared to students from public institutions. Nevertheless, both public and private higher education institutions should apply the same customer-oriented services in several aspects of the education services in order to satisfy the needs of their customers.

Although the researchers attempted to provide the necessary rigour to the project, there were still limitations to it. The sample was selected from students in the Jakarta area (in Indonesia), and thus it might not be representative of the total population of HEI students. A wider sample should be investigated to improve the possibility of generalization of the results. Secondly, although SCOQ provided a tool to investigate the issue of education, the population might have culture-spe- 
cific attributes in a country context that may affect the findings. It might thus be worth further investigating in future.

Acknowledgements

We would like to acknowledge that this work is based on the research supported in part by the Tshwane University of Technology (TUT), South Africa, through the Department of Higher Education and Training Research Development Grant. This study was also supported in part by Indonesia Banking School, Indonesia.

\section{References}

Amiri, E., Ranjbar, A.P.D.M. \& Zamani, H. (2015). New Management Approaches in Higher Education. The Online Journal of Quality in Higher Education, 2(3), 92.

Argenti, P. (2000). Branding B-schools: Reputation management for MBA programs. Corporate Reputation Review, 3(2), 171-178.

Brown, T.J., Mowen, J.C., Donavan, D.T. \& Licata, J.W. (2002). The customer orientation of service workers: Personality trait effects on self-and supervisor performance ratings. Journal of Marketing Research, 39(1), 110-119.

Eagle, L. \& Brennan, R. (2007). Are students customers? TQM and marketing perspectives. Quality assurance in education, 15(1), 44-60.

Fontaine, M. (2014). Student Relationship Management (SRM) in Higher Education: Addressing the Expectations of an Ever Evolving Demographic and Its Impact on Retention. Journal of Education and Human Development, 3(2), 105-119.

Guilbault, M. (2018). Students as customers in higher education: The (controversial) debate needs to end. Journal of Retailing and Consumer Services, 40, 295-298.

Judson, K.M. \& Taylor, S.A. (2014). Moving from marketization to marketing of higher education: The co-creation of value in higher education. Higher Education Studies, 4(1), 51.

Koris, R. \& Nokelainen, P. (2015). The student-customer orientation questionnaire (SCOQ) Application of customer metaphor to higher education. International Journal of Educational Management, 29(1), 115-138.

Koris, R. (2012). Customer orientation model for a higher education institution: when is student-customer orientation appropriate? International Scientific Publications: Educational Alternatives, 10(1), 261-277.

Narver, J.C. \& Slater, S.F. (1990). The effect of a market orientation on business profitability. The Journal of marketing, 20-35.

Muncy, J.A. (2008). The orientation evaluation matrix (OEM): Are students customers or products? Marketing Education Review, 18(3), 15-23.

Pesch, M., Calhoun, R., Schneider, K. \& Bristow, D. (2008). The student orientation of a college of business: An empirical look from the students' perspective. The Marketing Management Journal, 18(1), 100-108. 
Sawilowsky, S.S. (2009). New effect size rules of thumb. Journal of Applied Statistical Methods,8 (2), 597-599.

Slater, S.F. \& Narver, J.C. (1998). Customer-led and market-oriented: Let's not confuse the two. Strategic management journal, 1001-1006.

Svensson, G. \& Wood, G. (2007). Are university students really customers? When illusion may lead to delusion for all!. International Journal of Educational Management, 21(1), $17-28$.

UNESCO Institute for Statistics. (2014). Higher Education in Asia: Expanding Out, Expanding Up: the Rise of Graduate Education and University Research. UNESCO. 